\title{
Игнатьева Н.Д. \\ Модели и опыт местного самоуправления в зарубежных странах
}

Бурятский государственный университет (Россия, Улан-Удэ)

doi:10.18411/spc-20-10-2017-03

idsp: 000001:spc-20-10-2017-03

\section{Аннотация}

Статья посвящена мировому опыту организации местного самоуправления и самоуправления за рубежом, прежде всего в развитых странах Европы и США. Автор анализирует англо-саксонские, континентально-европейские и смешанные системы функционирования МСУ с точки зрения адаптации их основных принципов к российским региональным особенностям

Ключевые слова: местное самоуправление, местное управление, англосаксонская модель, континентальная модель, смешанная модель, муниципальная власть.

Местное самоуправление за рубежом имеет различные формы зависимости от того, на сколько он взаимосвязан с системой государственного управления и какая у него автономность. Значительная роль в распространении мысли о местном самоуправлении началась в 1831 году. В ней была опубликована специальная статья, посвященная управлению общинами.

Наряду с законодательной, исполнительной и судебной выделяется власть четвертая - муниципальная.

Сегодня в западных странах принято различать три модели местного управления: англосаксонская, континентальная и «смешанная». Различия между этими моделями в основном основывается в первую очередь на отношениях между местными органами власти и высшими органами власти.

В рамках англосаксонской модели, которая была расширена в Великобритании, США, Канаде, Австралии и других государствах с англосаксонской правовой концепцией, где местные представительные органы официально выступают в пределах своих полномочий, без прямого подчинения вышестоящих органам. В этом отношении нет прямого подчинения нижестоящих органов отсутствует. Для этой модели нет избранных представителей центра, а существует выборные органы местного самоуправления - Советы. На местном уровне нет прямых правительственных органов, поэтому советы в некотором смысле сами являются такими органами, поскольку власти направляются им парламентом. Аналогичным образом, советы имеют право просить парламент предоставить власть.

Вся деятельность руководства осуществляется через советчиков, комиссий и административных органов. Значительные полномочия возлагаются на комиссии (или комитеты) местных представительных органов, исполняющие существенную значимость в решении главных вопросов.

Взаимосвязь между центральными и местными органами власти, где существует англосаксонская модель, регулирует принцип «действия в пределах своих полномочий». Таким образом, право делегировать полномочия строго закреплено в нормативном порядке. Все другие действия считаются совершенными судом незаконными.

В некоторых штатах муниципальные власти, независимо от центра, решают вопросы местного значения в рамках, конечно же, предоставленных им полномочий. 
Характерные особенности модели:

1. муниципалитеты рассматриваются как независимые субъекты, осуществляющие полномочия, возложенные на них парламентами;

2. полномочные представители правительства не находятся на местах, которые опекают местные выборные органы;

3. правительство оказывает влияние на то, каким образом местное правительство действует в рамках своих полномочий, то контроль ограничивается согласованием вопросов через министерство.

4. отношения между центральным правительством и муниципалитетами по принципу «действующего в пределах их полномочий». В противном случае они не могут быть признаны судом.

Как и англосаксонская модель, континентальная модель системы организации местного самоуправления имеет свои преимущества и недостатки. Среди основных различий между континентальной моделью и англосаксонским заключается характер взаимоотношений между местными органами власти и государственными органами. В рамках континентальной модели идеи государственного самоуправления стали более распространенными, поскольку они основаны на административной заботе органов самоуправления.

К положительным факторам необходимо относить то, что в государствах с французской системой местного самоуправления муниципалитеты, в отличие от стран, англосаксонского типа, могут осуществлять власть на национальном уровне. Таким образом, во Франции муниципалитеты участвуют в выборах в Сенат (верхняя палата парламента), поскольку их члены представляют большинство соответствующих избирательных коллегии. Таким образом, он позволяет населению, его представителям в избранных органах самостоятельно решать местные вопросы. Однако чиновник, который осуществляет контроль над местным самоуправлением, комиссаром республики, префектом, супрефектом, назначается «сверху», независимо от воли местного населения. Закон не обязывает правительство, по крайней мере, координировать такое назначение с местным советом.

Характерные особенности модели:

1. Высокая степень централизации местного самоуправления.

2. Разработана система административного контроля центральной власти над местными органами власти.

3. Муниципалитеты допускают все действия, которые прямо не запрещены законом и не входят в компетенцию других органов.

В конечном итоге, не мало важно выделить, что в некоторых странах и регионах, таких как Австрия, Германия, Япония, Латинская Америка, функционирует смешанная модель управления, которая имеет сходство с англосаксонской и континентальной моделями с ее особыми особенностями. Например, в Латинской Америке предварительно избранные населением, как правило, одобряются парламентом как представитель государственной власти и в то же время направляют местный совет.

В Германии главы местных администраций одновременно являются государственными чиновниками. Губернатор Японская префектура, избранная местным населением и считающаяся главой местной администрации, выполняет ряд национальных функций.

Характерные особенности модели:

1. Местные органы формируются в районах, в городах в чине районов и общин;

2. Общины выполняют все административные функции, за исключением случаев, когда эти функции возлагаются на другие структуры управления.

3. Общины регулируют сферу своей деятельности через устав. 
4. Община имеет право самостоятельно решать проблемы.

Все модели местного самоуправления - результат естественного развития. В этих странах местное самоуправление возникло «снизу» и стало образом жизни, частью менталитета европейских народов.

Во всех моделях местного самоуправления неизменно наблюдается автономность самоуправляющихся территориальных единиц. Большинство современных моделей местного самоуправления имеют несколько уровней:

1. Сообщества, коммуны, муниципалитеты.

2. Сельская местность или город

3. Графства (префектура)

Все эти уровни имеют почти равные полномочия. Отношения между ними основаны на распределении компетенций и взаимодействии.

$$
* * *
$$

1. М.В.Баглай Конституционное право зарубежных стран, М., 2004, с. 291

2. Салов О. Местное самоуправление в современном мире // Федерализм, 2000, № 1, с. 175.

3. Емельянов Н.А. Муниципальные системы зарубежных стран. М., 1998.

4. Крылова Н.С. Английское государство. - М., 1981, с. 215.

5. Органы местного самоуправления в зарубежных странах. Сравнительное исследование. М., 1994 с $61-62$

\section{Колосова Е.Н. ${ }^{1}$, Миловидова С.Ф. ${ }^{2}$ \\ Некоторые аспекты проявления личных интересов человека в уголовном законодательстве России \\ ${ }^{1}$ УМВД России по г. Волгограду (Россия, Волгоград) \\ ${ }^{2}$ Московский университет МВД России имени В.Я. Кикотя \\ (Россия, Москва)}

doi:10.18411/spc-20-10-2017-04

idsp: 000001:spc-20-10-2017-04

Проблемы частного интереса в уголовном праве, хотя и не являются наиболее актуальными, тем не менее, все чаще в последнее время занимают внимание юристов. В этой связи представляется важным в рамках написания данной статьи обозначить некоторые аспекты этой проблемы, привлечь правоведов к обсуждению названной темы. Само слово «интерес» происходит от латинского «interest», что означает «иметь значение». Это понятие раскрывается следующим образом:

- особое внимание к чему-нибудь, желание вникнуть в суть, узнать, понять;

- занимательность, значительность;

- нужды, потребности;

- выгода, корысть;

- важность, значение;

- предмет, тема, приковывающее внимание;

- польза, смысл;

- желание.

Применительно к личному интересу можно сказать, что это особое внимание к чему-нибудь, занимательность, значительность, важность, сформировавшаяся в сфере частной жизни человека. Причем, необходимо отметить, что само наличие у индивида, личности частного интереса, хотя и является признаком отчуждения человека от государства, тем не менее, явление объективно существующее. Общеизвестно и, безусловно, что можно быть самым счастливым человеком в самом несправедливом 